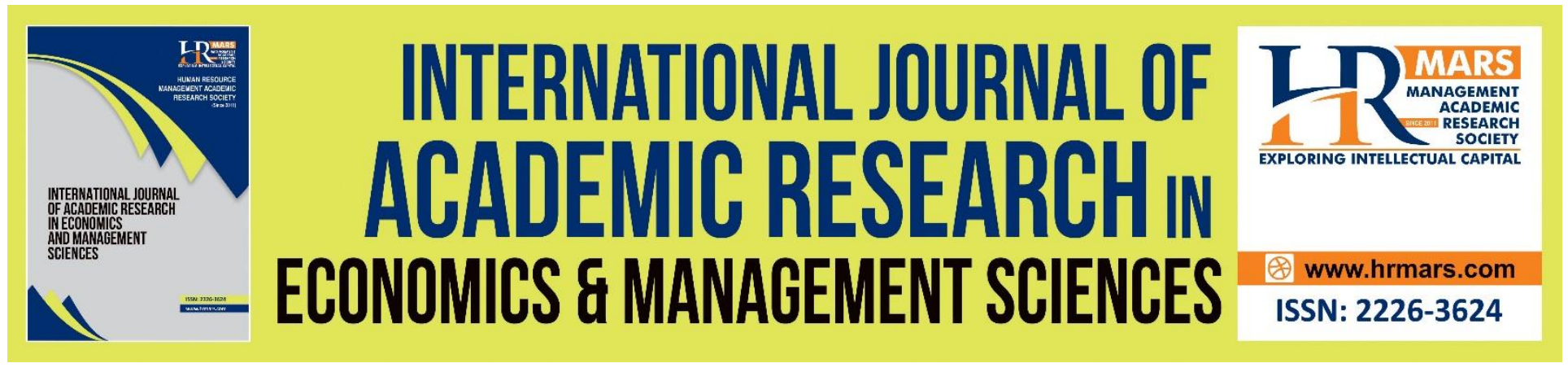

\title{
A Proposed of Halal Food Supply Chain Traceability Model
}

\section{Nor Azizah Binti Jasman, Nor Hapiza Binti Mohd Ariffin}

To Link this Article: http://dx.doi.org/10.6007/IJAREMS/v10-i3/11167 DOI:10.6007/IJAREMS/v10-i3/11167

Received: 09 July 2021, Revised: 29 July 2021, Accepted: 15 August 2021

Published Online: 20 September 2021

In-Text Citation: (Jasman \& Ariffin, 2021)

To Cite this Article: Jasman, N. A. B., \& Ariffin, N. H. B. M. (2021). A Proposed of Halal Food Supply Chain Traceability Model. International Journal of Academic Research in Economics and Managment and Sciences, 10(3), 401-417.

Copyright: (C) 2021 The Author(s)

Published by Human Resource Management Academic Research Society (www.hrmars.com)

This article is published under the Creative Commons Attribution (CC BY 4.0) license. Anyone may reproduce, distribute, translate and create derivative works of this article (for both commercial and non-commercial purposes), subject to full attribution to the original publication and authors. The full terms of this license may be seen

at: $\underline{\text { http://creativecommons.org/licences/by/4.0/legalcode }}$

Vol. 10, No. 3, 2021, Pg. 401 - 417

Full Terms \& Conditions of access and use can be found at http://hrmars.com/index.php/pages/detail/publication-ethics 


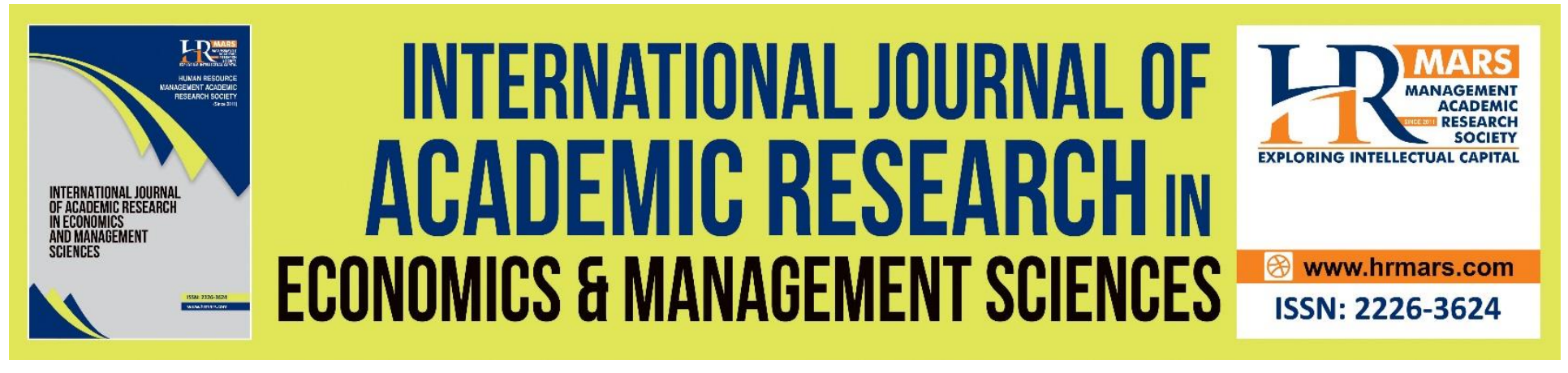

\title{
A Proposed of Halal Food Supply Chain Traceability Model
}

\author{
Nor Azizah Binti Jasman, Nor Hapiza Binti Mohd Ariffin \\ Faculty of Computer and Mathematical Sciences, Universiti Teknologi Mara, Shah Alam, \\ Selangor, Malaysia \\ Email: azahjasman99@gmail.com, hapiza@tmsk.uitm.edu.my
}

\begin{abstract}
The rise in Halal Food Supply Chain (HFSC) issues and the ongoing 2019 global coronavirus disease (COVID-19) pandemic accelerate the need for HFSC process compliance and the adoption of technologies to validate and verify the authenticity and integrity of the HFSC activity. However, the issues and factors in HFSC traceability in this context have yet to be specifically published in Malaysia. The absence of this study suggests an impending need for a study to be conducted to find the issues of HFSC traceability. Thus, this study aims to propose the Halal Food Supply Chain Traceability Model by identifying the factors for HFSC traceability. The halal food industry was considered as one of the case examples in the study. This study was undertaken using content analysis by identifying the issues and factors for HFSC traceability from previous researchers' twenty-three (23) studies. The study identified the contributing factors to HFSC traceability and proposed the HFSC traceability model. The benefits of knowledge gained could help the clarity and expectations of the solutions to the HFSC industry and as references or basic guidelines on HFSC traceability.

Keywords: Halal Food Supply Chain, Food Supply Chain, Traceability, Technology, Halal Traceability
\end{abstract}

\section{Introduction}

In general, the Food Supply Chain (FSC) is a cross-industry network ecosystem that works together to develop customer and consumer solutions. Each driver can directly influence the supply chain and enable certain capabilities. It highlights the issue of properly managing food supply chains since there is a great deal of worry and a rise in food safety and food compliance with specific religious requirements (Rejeb, 2018). The Halal Food Supply Chain (HFSC) is a critical business as the industries are responsible for producing food that is consumed daily by billions of people across the globe.

However, the integrity of the providers' processes, the authenticity, and the credibility of the products have become a global issue. For example, in January 2013, the Food Safety Authority of Ireland (FSAI) discovered that from 27 hamburger products, ten contained horse deoxyribonucleic acid (DNA) the other 23 positive pig DNA. As a result of the 'horsemeat crisis,' the Halal supply chain has gained traction due to a rise in Muslim market demands 
(Madichie \& Yamoah, 2017). The food falsification has badly affected the economy and the consumers' trust, which directly impacted all the stakeholders. In order to address the global FSC issue, the suggested solution is by tracking and authenticating the FSC (Galvez et al., 2018).

In order to get certifications such as "certified organic food," "certified GMO-free food," "certified Halal food," and other such certifications, the information gathered through the traceability system is used. Apart from these advantages, traceability systems are also necessary because they influence the effectiveness and performance of a company, the integrity of food, and the prevention of food adulteration (Haleem et al., 2019). Traceability contains the history of documented recognized processes and data history by utilizing certain technology tools on the location of the food and its ingredients. Data captured includes the history throughout the FSC cycle, for instance, the source of contamination (Girish \& Barbuddhe, 2019). HFSC traceability is important to address the growing concern on the HFSC fraud and the failure of HFSC traceability that implicate the food safety and the credibility of the HFSC industry. In addition, implementing a halal traceability system is critical to reduce contamination and ensure that it would not occur throughout the process of handling halal food in line with Shariah compliance standards (Ab Talib, 2017).

Hence, this research aims to identify the existing approaches and technology in solving the HFSC traceability and propose the overall framework variables abstracted from the literature review. The results of the study shall then be used as a reference or a basic guideline for study purposes by the new researchers, the HFSC industry, consumers as well as the Government agencies in understanding the HFSC issues, solutions adopted on the best practices of approaches, and the technology in tracking and authenticating HFSC.

\section{Literature Review}

\section{Halal Food Supply Chain (HFSC) Issues}

The term HSFC refers to the process of delivering Halal food from farm to fork while maintaining the product's Halal status (Rejeb, 2018). HSFC is defined as the process of managing the procurement, movement, storage and handling of materials, parts, livestock, semi-finished inventory food and non-food and related information, as well as documentation, flows across the supply chain following the general principles of Sharia law (Rashid et al., 2018). The explanation made by Vorst et al (2005) is that an FSC is a series of activities from the producer and information flows. It includes the producer and its suppliers and depends on the activities that include logistics, warehouses, retailers, and consumers themselves. As per Zhong et al (2017), FSC is the movement of food from farm to fork, including a multiplex web, food production by producers, vendors, processing, distribution, retailing, and consumption by consumers. In general, FSC is the whole process of the entire FSC until the delivery to the consumer (Lemma et al., 2014). It also projected a high increase in world population in 2050 and 2100 with an additional 1.2 billion and 2.7 billion, respectively (United Nations, 2020). With this increase and concerning research made by Lemma et al. (2014), the concern on the resources of the FSC is critically challenging; thus, a solution is to be created and maximize the availability of the resources to match with the population growth. This is also consistent with the rise in the Muslim community, which has placed a strong emphasis on the Halal certification of the food they consume. 
This definition of integrity could be related to being free of adulteration, misdescription, falsification, or contamination intentionally or unintentionally (Wahab \& Ling, 2019a). As time changes, the realization of healthy food also increases. Some may particularly demand highquality foods, and some may opt for fast food. This food may be produced locally or from another side of the country. Food producers frequently face problems authenticating the source of the food (Wen et al., 2020). Tracking and authenticating by accessing the HFSC history is essential for the industries. This is due to regulatory compliance and any other factors concerning product origin, identity, and quality. These factors are crucial due to the frequency of food safety issues (Dabbene et al., 2014). Consumers have become increasingly aware of the food scandals and demanded more information about the products before purchasing. The industries and the consumers' concern over the food quality gradually increasing (Duan et al., 2020). Muslim customers are mostly concerned about food items' adherence to Halal rules and Sharia law principles (Rejeb, 2018).

It was reported that almost 2,500 food-related incidents were reported in 2019/20 in England, Northern Ireland, and Wales. This represents a 6.7\% increase compared to 2018/19 reporting (Sullivan \& Randles, 2020). There is also a report made by the Grocery Manufacturers Association estimating that adulterated food is valued at USD 49 billion per year (Babich \& Hilary, 2019). Furthermore, it was quoted by the Food Standards Agency, United Kingdom, that livestock and livestock products are involved the most in food incidents (Sullivan \& Randles, 2020). The food falsification has badly affected the economy and the consumers' trust, which directly impacted all the stakeholders, especially the Muslim population. In order to address the global FSC issue, the suggested solution is by tracking and authenticate the food supply (Galvez et al., 2018). News by Bloomberg by Anuradha Raghu (2020), several senior officers of government agencies of Malaysia were allegedly involved in the importing meat that claimed to be a mixture of kangaroo and horse meat of which were sold as halal beef. However, Deputy Domestic Trade and Consumer Affairs Malaysia, Minister Datuk Rosol Wahid, has confirmed that the tests carried by the Malaysian Chemistry Department concerning the meat-fraud scandal showed that they are not pork, horse, or kangaroo meat (The Star, 2020). This explains the degree of implication to the government due to a lack of HFSC traceability.

\section{Existing Approaches and Technology}

The broad aspect of the HFSC circulation activities in line with the rapid growth of formal living and the evolution and awareness on food safety and quality influenced and became a push factor for the industries to utilize the relevant solutions and tools in managing the HFSC activities. The discussion below is on the existing approaches and technology applied for traceability in the HFSC industry.

\section{Approaches}

The consumer is concerned over the safe food security for consumption, and Halal has become unconditional. However, from production to all stages of HFSC activities, the food is exposed to contamination risk and Halal credibility exposures as there is no proper process control. There are a few approaches to handling food products to ensure food safety. It is required to meet a certain process benchmark following Halal requirements and subsequently be documented. These certified and recognized processes are evidence of food safety handling in the industry before adopting technology solutions in HFSC traceability. 


\section{SCIENCES}

Vol. 10 , No. 3, 2020, E-ISSN: $2226-3624$ @ 2020 HRMARS

\section{Approach 1 - Hazard Analysis and Critical Control Points (HACCP)}

The U.S. National Aeronautics and Space Administration (NASA) developed the HACCP in the 1960 s to ensure astronauts' food safety (Weinroth et al., 2018). Studies made by Feng Tian (2018) explained that HACCP is a systematic approach in identifying, evaluating, and controlling food safety hazards. A HACCP system is a preventive system of hazard control, and the objective was to prevent possible food safety issues. The standard HACCP process is to ensure that the risk of the potential hazards is mitigated. However, Sperber (2005) pointed out that the lack of definitive critical control points could hinder the objective of HACCP in the FSC. He believes that food safety control measures must be prioritized compared to the essential points of control from the HACCP system. Journal written by Weinroth et al. (2018) pointed out that although developed countries mostly adhered to core HACCP principles of food safety, ideas dealing with traceability, vulnerability to food fraud, and intentional adulteration have been considered further bolster food safety.

\section{Approach 2 - ISO22000:2018 Food Safety Management Systems (ISO)}

ISO22000:2018 FSMS is a certification by the International Standard Organisation that is currently adopted globally, enabling the FSC provider in planning and operate the product in a safe environment. It also demonstrates compliance with the applicable statutory and regulatory body in food safety requirements. It applies to the chain of FSC that consists of producers, manufacturers, logistic providers, warehouse operators, to retail and food outlets (Færgemand \& Jespersen, 2005). As per International Organization for Standardization (2018), with the certification, it is proven the FSC involved demonstrates its ability to control food safety hazards and ensure the food is safe for consumption. They also stressed that keeping food safe from farm to fork by ensuring hygienic practices and traceability at every step of the supply chain is essential for the food industry. ISO is one of the highest certification benchmarks that is recognized globally, and it is accredited by 165 national standard bodies, for instance, in Malaysia, the accredited body is Sirim QAS International Sdn Bhd.

\section{Approach 3 - Halal Compliance Critical Control Point (HCCCP)}

Halal Supply Chain includes production, procurement, and preparation of halal ingredients to the manufacturing and delivery that provides logistics to the end consumer. HCCCP is an official recognition of the industry's practice with HACCP elements (Ministry of Health Malaysia, 2021). HCCCP identified points within the overall operation, preparation, and processing of Halal food. The traceability in HSFC ranges from HCCCP, the manual documentation system, and a more complicated system using information technology software and tools (Samsi et al., 2012). Approach 1 and 2 on HACCP and ISO are both processes and documentation compliance without including Halal services and ingredients. The combination of HCCCP validates the process in Halal compliance. The presence of HSFC is vital as it strictly incorporates the Shariah principles throughout the supply chain management process, from the point of sourcing to the end of consumption.

\section{Technology}

The industry and the community are dependent on technology, and the Covid-19 pandemic is the enabler for the adoption of technology globally. Hence, the technology adoption in HFSC traceability strengthens the product quality, security, and safety throughout the FSC. 


\section{SCIENCES}

Vol. 10, No. 3, 2020, E-ISSN: 2226-3624 ㄷ 2020 HRMARS

\section{Technology 1 - RFID}

RFID technology consists of a microcontroller, a radio antenna, and a transmitter, which improves practicality by identifying product information from a distance or out of sight. Thus, to ensure that the product is safe and stored, the temperature is regulated by a microcontroller, the intelligent tags can be affixed or integrated into products' packaging (Moyeenudin, 2021). Daily scanning using RFID has exceeded over 5 billion products in 141 countries. RFID technology combined with appropriate information infrastructure enables traceability in the FSC (Kelepouris, 2014).

\section{Technology 2 - Internet of Things (IoT)}

FSC revolution is to improve the production efficiency as well as manage the quality reliance on technology. Built-in sensors inside devices and objects connected with an loT platform integrate data and interpret analytics comprised of valuable information (IBM, 2016). IoT also refers to integrating hardware equipped with sensors and actuators where it collects data (Cai et al., 2018). IoT is widely used in the FSC by integrating sensors/actuators, RFID tags, and communication technologies (Zhang et al., 2017; Coronado Mondragon et al., 2020). These have proven the industry's reliance on IoT and RFID in the FSC production cycle (Kelepouris, 2014).

\section{Technology 3 - Artificial Intelligence (A.I.)}

HFSC industries are huge and HFSC producers mostly produce on a large scale. Strategically as to maximize the revenue, the HFSC producers have to manage the risks by identifying the possible risk and the mitigation measures to be taken into consideration to avoid or minimize the unnecessary loss. Baryannis et al. (2019) found that proactive strategies rely on accurately predicting the likelihood of occurrence and the potential impact of risks. This necessary predictive capability can be achieved using techniques within the broad spectrum of A.I. Lu et al. (2018). The research described those robots and A.I. are actively studied in the United States. A.I. is used to perform and automate the work process. The A.I. has its benchmark embedded in the robots to identify a complete or incomplete product to go through the next process. The presence of A.I. provides support to the HFSC producer in decision making.

\section{Technology 4 - Blockchain}

The search for alternatives to the conventional supply chain has started due to declining trust and traceability issues (Madichie \& Yamoah, 2017). The implementation and utilization of blockchain could determine the substance and criticality of the HFSC traceability and authenticity problem. Furthermore, it also can choose blockchain solutions towards resolving the issue. A brief review made by Yaga et al. (2019) states that four main characters enable blockchain technology: a ledger, secure, shared and distributed. Blockchain can create a decentralized ledger tracing product from field to shelf. It provides full traceability and ensures the source of a product, product freshness, and all production standards are being met.

\section{Methods \& Materials}

The methodological research approach used in this article is a content analysis to determine the presence of certain words, topics, or concepts in certain qualitative data (Zailani, 2015). This study uses content analysis to identify the existing approaches and technology in HFSC traceability in the published literature. Qualitative research is done to precisely convert a vast 


\section{SCIENCES}

Vol. 10 , No. 3, 2020, E-ISSN: 2226-3624 @ 2020 HRMARS

volume of material into a clear and concise summary for the most significant results (Erlingsson \& Brysiewicz, 2017). Articles were collected from the repository of Emerald Insight, Research Gate, Science Direct, MDPI, and Google Scholar. Food integrity is a multidimensional concept that recognizes food quality, food security, and food protection as interdependent and mutually strengthening food integrity pillars, while standards and food security systems are recognized as fundamental mechanisms to improve the integrity of the food chain (Wahab \& Ling, 2019).

The scope of research narrowed on the research objective that was relevant for the period between 2017 until 2021. As a result, there were 29 articles studied, and six articles were discarded due to the irrelevant context of the objective and 23 papers were accepted. After that, data is analyzed and extracted by segregating the approaches and technology to solve the FSC traceability and identify the keywords. By referring to the research goal, we can concentrate on the research during the analysis findings (Erlingsson \& Brysiewicz, 2017). The focus was made on the common context of traceability in terms of approaches and technologies that consists of seven (7) keywords used for searching articles that include "Internet of Things (IoT), Radio-Frequency Identification (RFID), blockchain, Artificial Intelligence, International Standard Operating (ISO), Halal, and Hazard Analysis Critical Control Point (HACCP)", details extraction of resources is as per the data tabulated at Table 1.0 below. The author also identifies the researchers' common challenges, which will be deliberated further in the discussion.

Table 1.0: Approaches and Technology in FSC

\begin{tabular}{|l|l|l|}
\hline \multicolumn{1}{|c|}{ REPOSITORY } & \multicolumn{1}{|c|}{ KEYWORDS } & \multicolumn{1}{c|}{ AUTHOR AND YEAR } \\
\hline EmeraldInsight & IOT, RFID, Blockchain & $\begin{array}{l}\text { (Zhang et al., 2017; Zhong et al., 2017; } \\
\text { Sander et al., 2018) }\end{array}$ \\
\hline Sciencedirect & $\begin{array}{l}\text { IOT, RFID, Blockchain, ISO, } \\
\text { Halal, HACCP, Artificial } \\
\text { Intelligence }\end{array}$ & $\begin{array}{l}\text { (Al et al., 2017; Allata et al., 2017; Ab Talib, } \\
\text { 2017; Cai et al., 2018; Bakar \& Rosbi, 2019; } \\
\text { Baryannis et al., 2019; Coronado Mondragon } \\
\text { et al., 2020; Mohd Nawawi et al., 2020) }\end{array}$ \\
\hline MDPI & $\begin{array}{l}\text { IoT, Blockchain, Halal, } \\
\text { HACCP, RFID, Artificial } \\
\text { Intelligence }\end{array}$ & $\begin{array}{l}\text { (Haleem et al., 2019; M1irabelli \& Solina, } \\
\text { 2020; Saurabh \& Dey, 2021; Riahi et al., } \\
\text { 2021) }\end{array}$ \\
\hline $\begin{array}{l}\text { ISO, IOT, Blockchain, } \\
\text { (Zimon et al., 2020; Duan et al., 2020; Di } \\
\text { Vaio et al., 2020; Ahmed et al., 2021) }\end{array}$ \\
\hline Intelligence \\
GoogleScholar & $\begin{array}{l}\text { HACC, RFID, Artificial } \\
\text { Intelligence }\end{array}$ & $\begin{array}{l}\text { (Tian, 2018; Weinroth et al., 2018; Baryannis } \\
\text { et al., 2019) }\end{array}$ \\
\hline
\end{tabular}

\section{Findings}

The selected publications and papers provided sufficiently illustrate the extensive study in existing approaches and technology methods in solving FSC traceability. A total of 29 research articles were analyzed, of which six articles have been removed which were found irrelevant and beyond the scope of the study. Table 2.0 below summarizes the identified challenges of the approaches and technology solutions in FSC traceability: - 
Table 2. 0: Approaches and Technology Challenges in FSC

\begin{tabular}{|c|c|c|c|c|}
\hline NO & \multicolumn{2}{|c|}{ CONTEXT } & CHALLENGES & REFERENCES \\
\hline 1 & $\begin{array}{c}\text { Approa } \\
\text { ch }\end{array}$ & HACCP & $\begin{array}{l}\text { 1) HACCP is not a stand-alone system according to } \\
\text { the M.S. } 1480: 2007 \text {. } \\
\text { 2) Implementation must be supported with Prerequisite } \\
\text { Programs such as Good Hygiene Practices, Good } \\
\text { Manufacturing Practice, or other systems similar in } \\
\text { kind } \\
\text { 3) Developing nations are unable to adopt consistent } \\
\text { regulatory requirements in food safety }\end{array}$ & $\begin{array}{l}\text { (Weinroth et } \\
\text { al., 2018; } \\
\text { Saurabh \& } \\
\text { Dey, } 2021\end{array}$ \\
\hline 2 & $\begin{array}{c}\text { Approa } \\
\text { ch }\end{array}$ & ISO & $\begin{array}{l}\text { 1) Developing nations struggle with consistent food } \\
\text { safety standards regulation implementation } \\
\text { 2) If one supply chain link is threatened or absent, the } \\
\text { whole network will be affected } \\
\text { 3) The absence of benchmark information and the } \\
\text { degree of complexity of the product or service to be } \\
\text { supplied } \\
\text { 4) The cost of implementing traceability systems is } \\
\text { viewed as a barrier for supply chain participants. } \\
\text { 5) Lack of traceability investment in underdeveloped } \\
\text { nations has led to a large number of incidents of food } \\
\text { outbreaks and fraud activities }\end{array}$ & $\begin{array}{c}\text { (Allata et al., } \\
2017 ; \\
\text { Weinroth et } \\
\text { al., 2018; } \\
\text { Zimon et al., } \\
\text { 2020) }\end{array}$ \\
\hline 3 & $\begin{array}{c}\text { Approa } \\
\text { ch }\end{array}$ & Halal & $\begin{array}{l}\text { 1) Questionable on the product's Halal status as } \\
\text { Malaysian Halal certification scheme is divided into } \\
\text { food product/ beverages/ food supplement; food } \\
\text { premise/ hotel; consumer goods; cosmetic and } \\
\text { personal care; slaughterhouse; pharmaceutical; and } \\
\text { logistic. } \\
\text { 2) Companies are more motivated and concerned about } \\
\text { the internal process compliance instead of the benefit } \\
\text { they could gain broadly outside of the Company } \\
\text { 1) One of the relevant problems preventing the growth of } \\
\text { the worldwide halal food sector was the lack of } \\
\text { standardized Halal standards }\end{array}$ & $\begin{array}{l}\text { (Ab Talib, } \\
\text { 2017; Bakar } \\
\text { \& Rosbi, } \\
\text { 2019; Mohd } \\
\text { Nawawi et } \\
\text { al., 2020) }\end{array}$ \\
\hline 4 & $\begin{array}{c}\text { Technol } \\
\text { ogy }\end{array}$ & RFID & $\begin{array}{l}\text { 2) Quality perceptions and purchasing decisions depend } \\
\text { on complete traceability devices } \\
\text { 3) An inadequate grasp of technological challenges and } \\
\text { raw data manipulation } \\
\text { 4) Difficulties in enlisting the support by stakeholders, as } \\
\text { well as a lack of rules } \\
\text { 5) Food suppliers have a limited understanding of } \\
\text { technology, which may jeopardize the system's } \\
\text { benefits. }\end{array}$ & $\begin{array}{l}\text { (Cai et al., } \\
\text { 2018; Sander } \\
\text { et al., 2018; } \\
\text { Duan et al., } \\
\text { 2020; } \\
\text { Coronado } \\
\text { Mondragon } \\
\text { et al., 2020; }\end{array}$ \\
\hline
\end{tabular}




\begin{tabular}{|c|c|c|c|c|c|}
\hline & & & & & $\begin{array}{l}\text { Saurabh \& } \\
\text { Dey, 2021) }\end{array}$ \\
\hline 5 & $\begin{array}{c}\text { Technol } \\
\text { ogy }\end{array}$ & IOT & $\begin{array}{l}\text { 4) } \\
\text { 5) } \\
\text { 6) }\end{array}$ & $\begin{array}{l}\text { Quality perceptions and purchasing decisions depend } \\
\text { on complete traceability devices } \\
\text { An inadequate grasp of technological challenges and } \\
\text { raw data manipulation } \\
\text { Difficulties in enlisting the support by stakeholders, as } \\
\text { well as a lack of rules } \\
\text { Food providers lack thorough knowledge of technology, } \\
\text { which might jeopardize the system's benefits. } \\
\text { Malicious attacks on traceability devices might be } \\
\text { feasible. } \\
\text { Possible issues in data integrity, tampering, and single } \\
\text { points of failure } \\
\text { Data integrity is possible inaccurate } \\
\text { loT data event incoherence sent from several IOT data } \\
\text { sources }\end{array}$ & $\begin{array}{c}\text { (Duan et al., } \\
\text { 2020; } \\
\text { Mirabelli \& } \\
\text { Solina, 2020; } \\
\text { Ahmed et al., } \\
\text { 2021) }\end{array}$ \\
\hline 6 & $\begin{array}{c}\text { Technol } \\
\text { ogy }\end{array}$ & $\begin{array}{l}\text { Artificia } \\
\qquad \\
\text { Intellig } \\
\text { ence }\end{array}$ & $\begin{array}{l}\text { 1) } \\
\text { 2) } \\
\text { 3) }\end{array}$ & $\begin{array}{l}\text { A.l. integration may influence the human workforce } \\
\text { Breach of data privacy } \\
\text { Some stakeholders are unable to cope with technology }\end{array}$ & $\begin{array}{l}\text { (Baryannis et } \\
\text { al., 2019;Di } \\
\text { Vaio et al., } \\
\text { 2020;Riahi et } \\
\text { al., 2021) }\end{array}$ \\
\hline 7 & $\begin{array}{c}\text { Technol } \\
\text { ogy }\end{array}$ & $\begin{array}{c}\text { Blockch } \\
\text { ain }\end{array}$ & 1) & $\begin{array}{l}\text { Quality perceptions and purchasing decisions depend } \\
\text { on complete traceability devices } \\
\text { An inadequate grasp of technological challenges and } \\
\text { raw data manipulation } \\
\text { Difficulties in enlisting the support by stakeholders, as } \\
\text { well as lack of rules } \\
\text { Due to the huge number of users and transactions in } \\
\text { one FSC. } \\
\text { FSC stakeholders with a lack of technological expertise } \\
\text { may jeopardize blockchain's benefits } \\
\text { Blockchain relies on more than } 51 \text { per cent of devices to } \\
\text { link, which might lead to potentially harmful assaults by } \\
\text { an assailant attacking Internet infrastructure. }\end{array}$ & $\begin{array}{c}\text { (Sander et al., } \\
\text { 2018; Cai et } \\
\text { al., 2018; } \\
\text { Duan et al., } \\
\text { 2020; } \\
\text { Mirabelli \& } \\
\text { Solina, 2020) }\end{array}$ \\
\hline
\end{tabular}

\section{Discussion}

This study summarizes the common practice of the seven key aspects of approach and technology for HFSC traceability through a comprehensive study from the gathered articles. Several common challenges were found because the approaches and technologies used were linked and integrated. Findings were not limited to the benefit but also extended to the challenges to understanding the gaps of the existing HFSC traceability solutions. Therefore, this study is relevant to the stakeholders in HFSC. This article's explanation and summary sections are 
based on a comprehensive literature study conducted specifically for this topic and the author's comments on research reviewed and experience.

\section{Approaches}

The traceability system has made production more efficient. It explains that these systems have made it possible to track the raw materials' quality and take immediate action if safety issues are reported (Allata et al., 2017). This emphasizes that the context of traceability is not just dependent on technology. It also relates to the HFSC stakeholders' production process approach. The halal food industry has become one of the key industries in Malaysia, and it is growing and recognized worldwide. Based on the challenges highlighted, the author agrees on the challenges faced by the Halal industry that no specific standards or practices are being introduced at the industry level. The HFSC is a realistic example of a strong FSC that uses the farm-to-fork concept to prevent contamination and food integrity violations (Wahab \& Ling, 2019). If a food contains imported components, each must be inspected for halal status, resulting in supply chain investigations.

As for HACCP, the author believes that since it is required, the other Prerequisite Programs as quoted by the author in Table 2.0, item (2), where the cost of implementing it in the FSC is possible higher as it is required different consultation and advice as well as a different accreditation body of compliance for the FSC to adhere. Thus, the implementation is quite massive as it contains a different process of compliance. The next approach is the adoption of the ISO process in the FSC activities. ISO has been recognized and accepted globally. However, it is noted that due to the complexity degree each FSC products process may carry, a different result of the process and the lack of supervision in implementing the ISO may be difficult for some FSC stakeholders.

To summarize, all the 3 FSC traceability approaches consisting of Halal, HACCP, and ISO are the quality assurance in ensuring the process in the FSC cycle is transparent and adhered to the Standards benchmark. However, the common challenges that the system is facing are, first, the cost involved in implementing it, requiring a certified subject matter expert to advise and massive documentation involved-secondly, the lack of governance and regulation involved in stressing the importance certify the process certification. In addition, the adoption of Halal criteria on top of the other accreditation approaches is an effective solution in terms of recognizing and validating the Halal credibility in HSFC.

\section{Technology}

Traceability is used to meet consumer expectations, provide optimal product flow management, and enhance speed across the FSC. This could be implemented through several technologies (Khan et al., 2018). In this paper, the author selected the most common technologies mentioned in the FSC traceability: RFID, IoT, A.I., and Blockchain.

RFID hardware severely limits the computational capability of its parts, particularly the tag. As a result, traditional approaches based on public-key cryptography or symmetric key primitives cannot be used (D'Arco \& De Prisco, 2018).

As for loT, certain features, such as deployment, mobility, and complexity, have caused severe security weaknesses that cannot be accepted (Neshenko et al., 2019). The author also agreed that, as stated in Table 2.0, item (5), the malicious assault on loT devices might violate data 
security, leading to the inaccuracy of data reported. Therefore, a proactive strategy to safeguard the loT ecosystem is important.

The author also concurred with the concern on A.I. implication on the human workforce as the tendency to rely on technology beyond A.I. could also threaten the human force's need.

As per Rn (2020), he quoted that blockchain comprises a large quantity of transaction data. Therefore, each block takes up a large amount of storage space, and where a large number of blocks are interconnected to create the blockchain, causing storage difficulties. As for the issue of scalability, it arises when the number of blocks in a blockchain grows. As a result, systems cannot cope with the increased system speed, which subsequently jeopardizes the system's performance.

Based on the review made on the past research as per Table 2.0, the author agrees with the researchers on the common opinion of challenges for the four technologies. Firstly, the success of traceability in the HFSC industry depends on other systems devices. Therefore, the acceptance and adoption of the technologies in the HFSC industry are crucial to materialize a complete HFSC cycle traceability. The lack of technology will also be a hindrance that may cause the HFSC stakeholders to be unable to achieve a competitive advantage in the industry. The most important is the support by the Government or the regulatory body in enforcing the industry to adopt the application of technologies in HFSC traceability in ensuring the consumers are protected.

\section{Food Supply Chain Traceability Model}

Based on the L.R. and the findings and challenges discussed earlier, the author suggests an HFSC traceability model of which the identification is made based on the independent variables as per Table 2.0 and Figure 1.0 below. A Variable is defined as a statistic or an individual observation (Ryan, 2006). 
INTERNATIONAL JOURNAL OF ACADEMIC RESEARCH ECONOMICS AND MANAGEMENT SCIENCES Vol. 10 , No. 3, 2020, E-ISSN: 2226-3624 @ 2020 HRMARS

Table 2.0: Food Supply Chain Variables

\begin{tabular}{|c|l|l|l|}
\hline No & \multicolumn{1}{|c|}{ Variables } & \multicolumn{1}{|c|}{ Definition } & \multicolumn{1}{|c|}{ Author } \\
\hline 1 & Food Safety & Safe and not harmful for consumptions & (Abdullah Sani \& Dahlan, \\
\hline 2 & Accreditation & $\begin{array}{l}\text { To eliminate haram and doubtful concerns, } \\
\text { Muslim consumers require food } \\
\text { certification that includes halal principles } \\
\text { and safety and quality elements. }\end{array}$ & (Ab Talib, 2017) \\
\hline 3 & $\begin{array}{l}\text { Process } \\
\text { Accuracy }\end{array}$ & $\begin{array}{l}\text { FSC process implementation guided by a } \\
\text { structured quality control system } \\
\text { established by the Standards }\end{array}$ & (Casino et al., 2020) \\
\hline 4 & $\begin{array}{l}\text { Perceived of } \\
\text { Trust }\end{array}$ & $\begin{array}{l}\text { Complete FSC production processes are } \\
\text { compulsorily recorded as per ISO }\end{array}$ & (Casino et al., 2020) \\
\hline 5 & $\begin{array}{l}\text { Process } \\
\text { Compliance }\end{array}$ & $\begin{array}{l}\text { Leverage and comply with the application of } \\
\text { technological innovations for efficient data } \\
\text { recording and exchange of information }\end{array}$ & (Baryannis et al., 2019) \\
\hline 6 & $\begin{array}{l}\text { Perceived of } \\
\text { Risks }\end{array}$ & $\begin{array}{l}\text { Minimize the risk through effective } \\
\text { utilization of technology }\end{array}$ & (Baryannis et al., 2019) \\
\hline 7 & $\begin{array}{l}\text { Minimize Loss } \\
\text { Reduce loss and waste by managing the flow } \\
\text { of products in the supply chain with decision } \\
\text { support systems and information } \\
\text { technology }\end{array}$ & (Lemma et al., 2014) \\
\hline $\begin{array}{l}\text { Decentralized } \\
\text { Ledger }\end{array}$ & $\begin{array}{l}\text { Antegrity and manipulation } \\
\text { intabase system for managing data }\end{array}$ & (Mirabelli \& Solina, 2020) \\
\hline
\end{tabular}

Figure 2.0: Halal Food Supply Chain Traceability Model

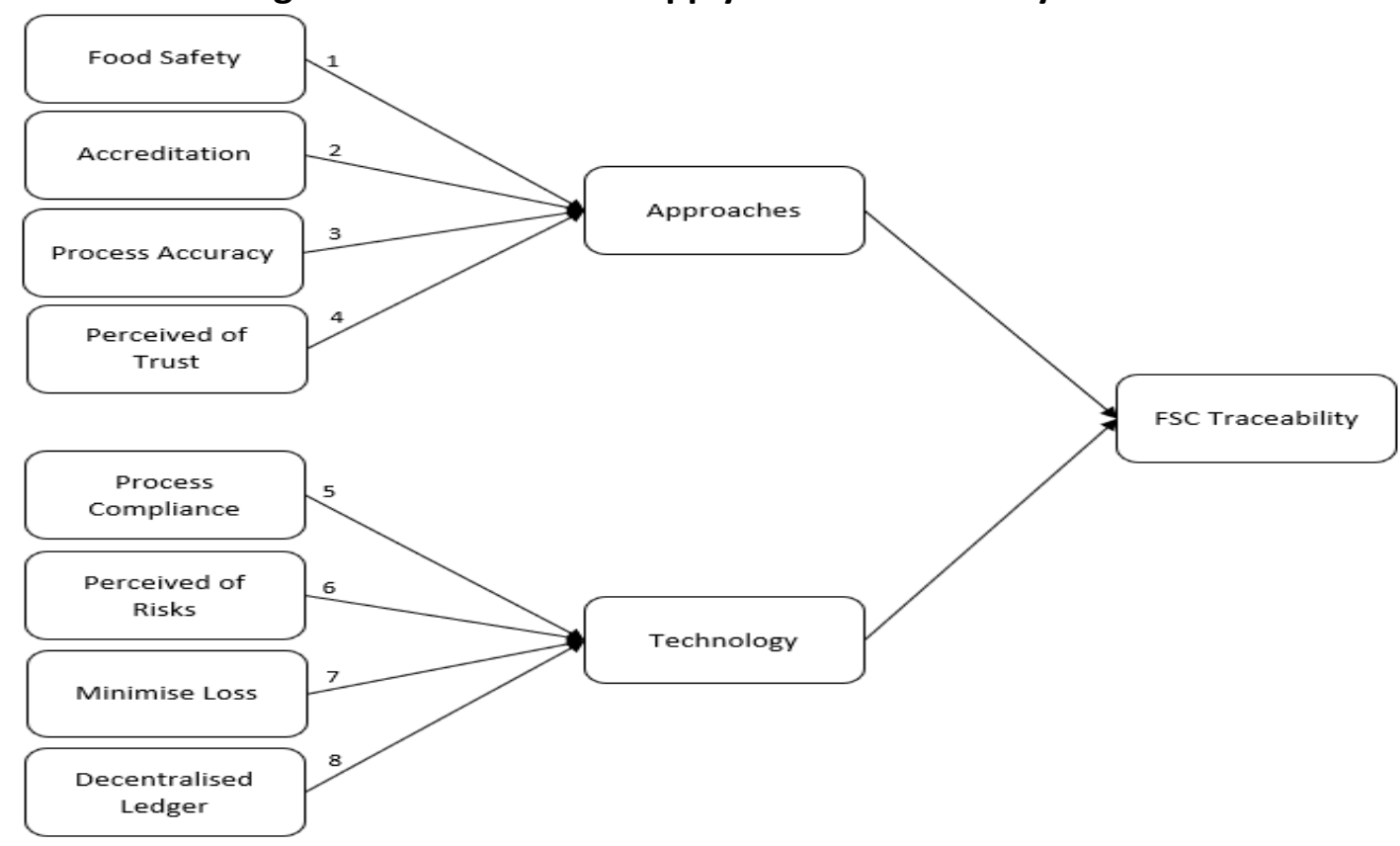


The approaches independent variables were derived from the perspective of hazard prevention in the production of food processes to avoid possible food safety problems. By complying with the Halal accreditation throughout the Halal Supply Chain Management process, the producers would mitigate any potential risks in producing the food and have the production accredited with Halal. HFSC's activity process is accurate due to this compliance which is supervised by a quality control system. In addition, the whole HFSC manufacturing process must be documented to instill a sense of confidence and reliability in the information being supplied.

As for the technology, the independent variables on process compliance are leveraging and complying with the proper application of technological innovations for efficient data recording and exchange of information. Thus, it could minimize risk exposures and financial loss by managing the HFSC process with technology. This is due to the technology's ability embedded in tools and devices to identify a complete or incomplete product and provide traceability to help HFSC producers make decisions. In addition, the decentralized ledger provides complete traceability from field to shelf.

\section{Conclusion}

Food adulteration, fraud, and food contamination incidents have occurred unprecedentedly, undermining consumer confidence in the food they consume. Such contamination is a significant problem among Muslim consumers, and these occurrences precisely created the drives in implementing a traceability system into the food industry. Thus, this study aims to find the presence approach and technology in HFSC traceability.

Understanding the basic components of existing HFSC traceability approaches and technologies could help clarify the functions of the solutions. The discussion of the challenges that stakeholders may face was also highlighted to identify and manage the risks. The proposed HFSC traceability model, as per Figure 1.0, is a great help for clarity on the requirement of HFSC traceability for future reference. It is also important to understand the relationship between the approaches and the technology to achieve the goal of successful HFSC traceability. The context of success for this study is when the food quality and safety control process system and the traceability tools and application could lead to a credible HFSC traceability reporting.

The above studies were limited to the results of previous research. It suggests the component in existing approaches and technologies of HFSC traceability for a common understanding, importance and challenges. However, it does not contain a case study of the relationship between these components. Therefore, future work should be considered in analyzing the relationship between these components in the HFSC industry.

In the future, this research can be used as a starting point for understanding HFSC traceability criteria and the needs and relationships between the techniques and technologies. Future research should examine the flow of approaches and technologies and then conduct a stakeholder survey on HFSC traceability solutions to measure the uptake of the solutions.

\section{References}

Ab Talib, M. S. (2017). Motivations and benefits of halal food safety certification. Journal of Islamic Marketing, 8(4), 605-624. https://doi.org/10.1108/JIMA-08-2015-0063

Sani, A. N., \& Dahlan, H. A. (2015). Current Trend for Food Safety and Halal Measures. ASEAN Community Conference 2015, November 11-12. 
INTERNATIONAL JOURNAL OF ACADEMIC RESEARCH ECONOMICS AND MANAGEMENT SCIENCES Vol. 10, No. 3, 2020, E-ISSN: 2226-3624 @ 2020 HRMARS

Ahmed, M., Taconet, C., Ould, M., Chabridon, S., \& Bouzeghoub, A. (2021). IoT data qualification for a logistic chain traceability smart contract. Sensors, 21(6), 1-25. https://doi.org/10.3390/s21062239

Al, G., Rhee, J., Ahn, H., Lee, J., \& Farooq, U. (2017). Integration of RFID, Wireless Sensor Networks, and Data Mining in an e- Pedigree Food Traceability System Integration of RFID, wireless sensor networks, and data mining in an e-pedigree food traceability system. Journal of Food Engineering, September 2021. https://doi.org/10.1016/j.jfoodeng.2017.05.008

Allata, S., Valero, A., \& Benhadja, L. (2017). Implementation of traceability and food safety systems (HACCP) under the ISO 22000:2005 standard in North Africa: The case study of an ice cream company in Algeria. Food Control, 79(September), 239-253. https://doi.org/10.1016/j.foodcont.2017.04.002

Raghu, A. (2020, December 30). Fake Halal Meat Scandal in Muslim-majority Malaysia Fuels Anger. Bloomberg LP, 2. https://www.bloomberg.com/asia

Babich, V., \& Hilary, G. (2019). Distributed Ledgers and Operations: What Operations Management Researchers Should Know about Blockchain Technology To cite this version : HAL Id : Hal-02005158 Distributed Ledgers and Operations : What Operations Management Researchers Should Know about. Manufacturing and Service Operations Management, INFORMS, In Press, hal-020051. https://hal.archives-ouvertes.fr/hal-02005158/document

Bakar, N. A., \& Rosbi, S. (2019). Robust Framework of Halal Certification Process With Integration of Artificial Intelligent Method. Journal of Islamic, Social, Economics and Development (JISED), 4(20), 47-55.

https://www.researchgate.net/profile/Nashirah_Abu_Bakar/publication/334068166_ROB UST_FRAMEWORK_OF_HALAL_CERTIFICATION_PROCESS_WITH_INTEGRATION_OF_ARTIFI CIAL_INTELLIGENT_METHOD/links/5d1551a5299bf1547c842275/ROBUST-FRAMEWORKOF-HALAL-CERTIFICATION-PROCESS-

Baryannis, G., Validi, S., Dani, S., \& Antoniou, G. (2019). Supply chain risk management and artificial intelligence: state of the art and future research directions. International Journal of Production Research, 57(7), 2179-2202. https://doi.org/10.1080/00207543.2018.1530476

Cai, W., Wang, Z., Ernst, J. B., Hong, Z., Feng, C., \& Leung, V. C. M. (2018). Decentralized Applications : The Blockchain-Empowered Software System. IEEE Access, P.P. (October), 1. https://doi.org/10.1109/ACCESS.2018.2870644

Casino, F., Kanakaris, V., Dasaklis, T. K., Moschuris, S., Stachtiaris, S., Pagoni, M., \& Rachaniotis, N. P. (2020). Blockchain-based food supply chain traceability: a case study in the dairy sector. International Journal of Production Research, 0(0), 1-13.

https://doi.org/10.1080/00207543.2020.1789238

Coronado Mondragon, A. E., Coronado Mondragon, C. E., \& Coronado, E. S. (2020). Managing the food supply chain in the age of digitalization: a conceptual approach in the fisheries sector. Production Planning and Control. https://doi.org/10.1080/09537287.2020.1733123

D'Arco, P., \& De Prisco, R. (2018). Design weaknesses in recent ultralightweight rfid authentication protocols. IFIP Advances in Information and Communication Technology, 529, 3-17. https://doi.org/10.1007/978-3-319-99828-2_1

Dabbene, F., Gay, P., \& Tortia, C. (2014). Traceability issues in food supply chain management: A review. Biosystems Engineering, 120, 65-80.

https://doi.org/10.1016/j.biosystemseng.2013.09.006 
Di Vaio, A., Boccia, F., Landriani, L., \& Palladino, R. (2020). Artificial intelligence in the agri-food system: Rethinking sustainable business models in the COVID-19 scenario. Sustainability (Switzerland), 12(12). https://doi.org/10.3390/SU12124851

Duan, J., Zhang, C., Gong, Y., Brown, S., \& Li, Z. (2020). A content-analysis based literature review in blockchain adoption within the food supply chain. International Journal of Environmental Research and Public Health, 17(5). https://doi.org/10.3390/ijerph17051784

Erlingsson, C., \& Brysiewicz, P. (2017). African Journal of Emergency Medicine COMMENTARY A hands-on guide to doing content analysis. African Journal of Emergency Medicine, 7(3), 9399. https://doi.org/10.1016/j.afjem.2017.08.001

Færgemand, J., \& Jespersen, D. (2005). ISO 22000 to ensure the integrity of the food supply chain. October 2004, 21-24. http://www.iso.org/iso/tool_5-04.pdf

Tian, F. (2018). An information System for Food Safety Monitoring in Supply Chains based on HACCP, Blockchain and the Internet of Things. March. http://epub.wu.ac.at/

Galvez, J. F., Mejuto, J. C., \& Simal-Gandara, J. (2018). Future challenges on the use of blockchain for food traceability analysis. TrAC - Trends in Analytical Chemistry, 107(August), 222-232. https://doi.org/10.1016/j.trac.2018.08.011

Girish, P. S., \& Barbuddhe, S. B. (2019). Meat traceability and certification in meat supply chain. Meat Quality Analysis: Advanced Evaluation Methods, Techniques, and Technologies, 2(Fall), 153-170. https://doi.org/10.1016/B978-0-12-819233-7.00010-0

Haleem, A., Khan, S., \& Khan, M. I. (2019). Traceability implementation in food supply chain: A grey-DEMATEL approach. Information Processing in Agriculture, 6(3), 335-348. https://doi.org/10.1016/j.inpa.2019.01.003

IBM. (2016). What Is the Internet of Things? IBM: What Is the Internet of Things, 1-25. https://doi.org/10.1007/978-1-4842-6609-0_1

International Organization for Standardization. (2018). ISO 22000 - Food safety management. ISO-Standards.

http://www.iso.org/iso/home/standards/managementstandards/iso22000.htm

Kelepouris, T. (2014). RFID-Enabled traceability in the Food Supply Chain RFID-enabled traceability in the food supply chain. January. https://doi.org/10.1108/02635570710723804

Lemma, Y., Kitaw, D., \& Gatew, G. (2014). Loss in Perishable Food Supply Chain: An Optimization Approach Literature Review. International Journal of Scientific \& Engineering Research, 5(5), 302-311.

Lu, H., Li, Y., Chen, M., Kim, H., \& Serikawa, S. (2018). Brain Intelligence: Go Beyond Artificial Intelligence. Brain Intelligence: Go Beyond Artificial Intelligence, 24(2), 371-379. https://doi.org/10.1007/s12540-018-0053-3

Madichie, N. O., \& Yamoah, F. A. (2017). Horsemeat Scandal.

Ministry of Health Malaysia. (2021). Halal Critical Control Point. Food Safety \& Quality Division. http://fsq.moh.gov.my/v6/xs/page.php?id=208

Mirabelli, G., \& Solina, V. (2020). Blockchain and agricultural supply chains traceability: Research trends and future challenges. Procedia Manufacturing, 42(2019), 414-421. https://doi.org/10.1016/j.promfg.2020.02.054

Nawawi, M. S. A., Abu-Hussin, M. F., Faid, M. S., Pauzi, N., Man, S., \& Sabri, M. N. (2020). The emergence of halal food industry in non-Muslim countries: a case study of Thailand. Journal of Islamic Marketing, 11(4), 917-931. https://doi.org/10.1108/JIMA-05-2018-0082 
Moyeenudin, H. M. (2021). Application of RFID Technology for Food Safety Application of RFID Technology for Food Safety. November 2018.

Neshenko, N., Bou-Harb, E., Crichigno, J., Kaddoum, G., \& Ghani, N. (2019). Demystifying loT Security: An Exhaustive Survey on loT Vulnerabilities and a First Empirical Look on InternetScale IoT Exploitations. IEEE Communications Surveys and Tutorials, 21(3), 2702-2733. https://doi.org/10.1109/COMST.2019.2910750

Rashid, N. A., Supian, K., \& Bojei, J. (2018). Relationship between Halal Traceability System Adoptions on Halal Food Supply Chain Integrity and Performance. International Journal of Asian Social Science, 8(8), 569-579. https://doi.org/10.18488/journal.1.2018.88.569.579

Rejeb, A. (2018). Halal Meat Supply Chain Traceability based on HACCP, Blockchain and Internet of Things. Acta Technica Jaurinensis, 11(4), 218-247. https://doi.org/10.14513/actatechjaur.v11.n4.467

Riahi, Y., Saikouk, T., Gunasekaran, A., \& Badraoui, I. (2021). Artificial intelligence applications in the supply chain: A descriptive bibliometric analysis and future research directions. Expert Systems with Applications, 173(January), 114702.

https://doi.org/10.1016/j.eswa.2021.114702

Rn, K. (2020). Blockchain-based Secure Big Data Storage on Cloud. International Journal of Recent Technology and Engineering, 9(4), 37-45. https://doi.org/10.35940/ijrte.d4744.119420

Ryan, T. P. (2006). Modern Engineering Statistics. In Modern Engineering Statistics. https://doi.org/10.1002/9780470128442

Samsi, S. Z. M., Ibrahim, O., \& Tasnim, R. (2012). Review on Knowledge Management as a Tool for Effective Traceability System in Halal Food Industry Supply Chain.

Sander, F., Semeijn, J., \& Mahr, D. (2018). The acceptance of blockchain technology in meat traceability and transparency. British Food Journal, 120(9), 2066-2079. https://doi.org/10.1108/BFJ-07-2017-0365

Saurabh, S., \& Dey, K. (2021). Blockchain technology adoption, architecture, and sustainable agri-food supply chains. Journal of Cleaner Production, 284, 124731. https://doi.org/10.1016/j.jclepro.2020.124731

Sperber, W. H. (2005). HACCP does not work from Farm to Table. Food Control, 16(6 SPEC. ISS.), 511-514. https://doi.org/10.1016/j.foodcont.2003.10.013

Sullivan, C., \& Randles, P. (2020). INCIDENTS \& RESILIENCE ANNUAL REPORT 2019/20. September $1-18$.

The Star. (2020, December 30). Not pork or horse meat assures Rosol. 2. https://www.thestar.com.my/

United Nations. (2020). Population: Our growing Population. 1-5. https://www.un.org/en/sections/issues-depth/population/index.html\#: :text=Our growing population\&text=lt reached 5 billion in 1987and 6 billion in 1999.\&text=The world's population is expected, nearly 11 billion around 2100.

Vorst, J. Van Der, Beulens, A. J. M., \& Beek, T. A. Van. (2005). Innovations in logistics and ICT in food supply chain networks. January.

Wahab, S. N., \& Ling, E. K. (2019a). The integrity of Food Supply Chain: Going beyond Food Safety and Food Quality. International Journal of Productivity and Quality Management, 1(1), 1. https://doi.org/10.1504/ijpqm.2019.10019297

Wahab, S. N., \& Ling, E. K. (2019b). The integrity of Food Supply Chain: Going beyond Food Safety 
and Food Quality. International Journal of Productivity and Quality Management, 1(1), 1. https://doi.org/10.1504/ijpqm.2019.10019297

Weinroth, M. D., Belk, A. D., \& Belk, K. E. (2018). History, development, and current status of food safety systems worldwide. Animal Frontiers, 8(4), 9-15. https://doi.org/10.1093/af/vfy016

Wen, X. W., Marlin, J., Wen, Z. J., \& Yang, Z. H. (2020). Reviewing studies of radio frequency identification applications in supply chain for food safety. International Food and Agribusiness Management Review, 23(5), 747-757. https://doi.org/10.22434/ifamr2019.0181

Yaga, D., Mell, P., Roby, N., \& Scarfone, K. (2019). Blockchain Technology Overview. ArXiv. https://doi.org/10.6028/NIST.IR.8202

Zailani, S. (2015). Content Analysis on the Global Supply Chain Management Article information : August. https://doi.org/10.1108/BIJ-04-2013-0038

Zhang, Y., Zhao, L., \& Qian, C. (2017). Modeling of an loT-enabled supply chain for perishable food with two-echelon supply hubs. https://doi.org/10.1108/IMDS-10-2016-0456

Zhong, R., Xu, X., \& Wang, L. (2017). Food supply chain management: systems, implementations, and future research. Industrial Management and Data Systems, 117(9), 2085-2114. https://doi.org/10.1108/IMDS-09-2016-0391

Zimon, D., Madzik, P., \& Domingues, P. (2020). Development of key processes along the supply chain by implementing the ISO 22000 standard. Sustainability (Switzerland), 12(15), 1-22. https://doi.org/10.3390/su12156176 